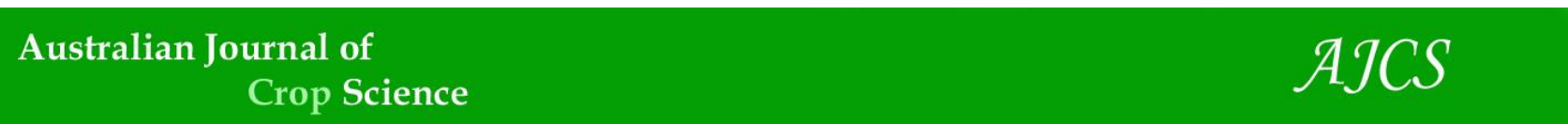

AJCS 15(10):1298-1306 (2021)

ISSN:1835-2707

doi: $10.21475 /$ ajcs.21.15.10.p3221

\title{
Assessment of Harmattan weather on cowpea (Vigna unguiculata, (L.) Walp.) production under drought stress
}

\author{
Vincent Ishola Esan ${ }^{1 *}$, Oluwafemi Oyeniyi Omilani ${ }^{2}$, Yewande Omoronike Osuntoyinbo ${ }^{1}$, Goodness \\ Toluwanimi Olutayo ${ }^{1}$, Titilayo E. Sangoyomi ${ }^{1}$
}

${ }^{1}$ Crop Production, Bowen University, Iwo, Nigeria

${ }^{2}$ Department of Horticulture, Oregon State University, USA

*Corresponding author: ishola.vincent@yahoo.com

\begin{abstract}
Drought stress is an environmental factor which restraints crop production and quality worldwide. It is now undeniable that drought limits the performance of crop plants. Annual water resources decline due to low rainfall and the reduction of the number of days of rainfall. The objectives were to: (1) screen existing cowpea genotypes at germination and seedling stages for their adaptation to water stress and (2) identify tolerant cowpea varieties to drought. The experiments were carried out both in the laboratory using an osmotic stress (laboratory drought stress) induced by polyethylene glycol 6000 (PEG 6000) and in an open field under different levels (control, moderate and severe) of drought conditions. Fourteen Cowpea varieties were used in this study. The drought stress was imposed on 21-days old seedlings and the experiment lasted for 3 months. In the laboratory, four treatments $0 \%, 6.5 \%, 13 \%$ and $16.5 \%$ PEG were used while in the open field two drought levels were imposed. The two experiments were laid out in randomized complete block design with three replications. Morphological, physiological and agronomic data were collected. Results showed that at high concentration (16.50\% PEG6000), high germination percentage was recorded in Raphael variety $(88 \%)$ followed by Tawa $(71.11 \%)$ and Eginwogogo $(60 \%)$ whereas germination was completely inhibited in ITG7K-449-35 variety. The morphological traits measured such as plant height, leaf width, leaf length was reduced by drought stress. The highest reduction (47\%) was recorded in the leaf width of Tiligre variety. In the second year of the experiment, IT99K-573-2-1 and Eginwogogo varieties plants died after 20 days of drought treatment because it could not withstand the drought stress condition during harmattan (a dry and dusty wind in West Africa) period due to the rapid dryness of soil moisture content. The results of dendrogram revealed that Raphael and Tawa were the most tolerant varieties.
\end{abstract}

Keywords: water stress, resistance, cowpea, high productivity. Abbreviations: PEG 6000: polyethylene glycol 6000

\section{Introduction}

Cowpea (Vigna unguiculata, (L.) Walp.) is a leguminous crop grown in the tropic. Cowpea is very important grain legume Africa and other parts of the world because it contains $23-$ $32 \%$ of protein and $64 \%$ of carbohydrate in its dry or fresh seeds. Leaves and the immature pods are used for human consumption. Moreover, the hay and dry seeds are used for animal feeding during the dry season (Chinma et al., 2008; Weng et al., 2017). Cowpea production has been a great source of income to farmers, traders and industries in many countries in the world (Langyintuo et al. 2003; Timko et al., 2007 and 2008; Lo et al., 2019). However, production of cowpea is limited in sub-Saharan Africa by numerous stresses, including salinity, nutrient deficiency, and drought. Water plays a vital role in the production of crop production including cowpea. In every part of the world, it is the limiting factor for agricultural crops (Ajayi et al., 2018). Lisar et al., (2012) stated that water is the core medium for carrying metabolites and nutrients and is a vital molecule in all physiological processes of plants. In the growth of plant, the response to shortage of water caused by drought has been a major force. Water stress is the most prevalent abiotic constraint that causes reduction in agricultural production (Robin et al., 2003). Nowadays, water availability for agriculture is becoming limited alongside with a projected rise in food demand for the expanding world population. Therefore, developing novel cultivars with more efficient water-use and greater drought-resistance capacity is the most viable solution to ensure a sustainable agricultural production and alleviate threats to food security (Mou, 2018). Indeed, the adoption and improvement of crops suited to growth with limited water resources on drought lands is vital to ensuring food security, given the seasonal variability, population growth, further compounded by the effects of climate change. In the developing counties, the development and use of crop varieties with high water use efficiency and high yield is particularly important for areas prone to drought, unreliable rainfall and where irrigation is unavailable or unaffordable for resource-poor farmers. Given that almost $90 \%$ of Nigeria's crops are rainfed, the huge season variability associated with change in climate such as drought pose a serious threat to farmers. Drought is the most severe environmental factors that affect crop 
production in West Africa. Crops grown under rainfed agriculture in the dry areas of tropical Africa are subject to dry hot conditions which are synonymous to drought (Carvalho et al., 2017). In sub-Saharan Africa, cowpea is mainly grown under rain fed system with a minimum annual rainfall of about $600 \mathrm{~mm}$ (Valenzuela and Smith, 2002). Thus, drought is a key abiotic constraint of cowpea yield in this production area (Singh et al., 1997).

Cowpea is mainly exposed to drought at the onset and the end of the rainy season (Singh and Matsui, 2002). Not only is drought sensitivity critical in seed germination and seedling growth, but their characters in relation to drought response are extremely important factors in determining yield (Rauf et al., 2007). It has been estimated that moisture or drought stress is the most adverse crop environmental stress, accounting for over $70 \%$ of potential agriculture yield losses worldwide (Boyer, 1982). In the same way, Kulkarni et al., (2008) stressed that crop yields are reduced by $70-80 \%$ due to a water stress situation specifically during the reproductive stage and are not able to fulfill the needs of food requirement in developed and developing countries of the world.

Polyethylene glycol 6000 has been used successfully to select drought resistant varieties at germination and seedling stage (Khodarahmpour, 2011; Almaghrabi, 2012; Ghebremariam et al., 2013; Esan et al., 2018). Alternatively, Deikman et al. (2012) suggested screening at reproductive stage - the most vulnerable stage in the life cycle of plants during drought conditions: "most non-field screens for drought tolerance have focused on vegetative stages, because of the relative ease and speed of obtaining data, despite the knowledge that water limitation at the time of flowering is the most damaging to crop productivity. Therefore, there is need to carry out experiments for better understanding of the mechanism behind drought tolerance in cowpea and identify the resistant cultivars for better yield in time of shortage of water. Therefore, the specific objectives of the present study were to (1) screen existing cowpea genotypes at germination, vegetative and reproductive stages for their adaptation to drought; and (2) identify tolerant cowpea varieties to drought conditions.

\section{Results}

\section{Effect of harmattan on cowpea varieties under drought stress}

In the second year of the experiment, IT99K-573-2-1 and EGINWOGOGO varieties plants died after 20 days of drought treatment because it could not withstand the drought stress condition during harmattan period due to the rapid dryness of soil moisture content. The harmattan weather in the first year was not as strong as the second year, thus all cowpea varieties including IT99K-573-2-1 and EGINWOGOGO survived the period coupled with drought. About $20 \%$ of the plants started flowering, mostly in third replication about 44 days after planting and by 53 days after planting all of the plants were already flowering and some of the plants under control drought condition started podding 56 days after planting.

ANOVA of germination percentage, morphological, agronomical and physiological characters of rice varieties grown at drought stress

The Analysis of the variance (Table 2 ) reveals that the variety had a very highly significant influence $(P \leq 0.0001)$, on germination percentage, plant height, number of lateral roots, days to flowering and days to podding while significant differences were observed on root length, leaf width, chlorophyll content and number of pods. No significant difference was observed with shoot length.

Drought as factor had a very highly significant influence $(P \leq 0.0001)$ on germination percentage, plant height, shoot length, leaf width, leaf length, number of pods, days to flowering and days to podding while significant differences $(p<0.05)$ were observed with chlorophyll content. No significant difference was recorded with root length.

Drought stress and variety interaction had a very highly significant effect $(P<0.001)$ on germination percentage and number of lateral roots while it had significant influence $(p<0.05)$ on plant height, chlorophyll content, days to flowering, days to podding and number of pods. This is an indication that the effect of drought treatment differed among varieties. The interaction between variety and water stress had no significant effect on root length, leaf width and leaf length.

Effect of PEG 6000 on germination percentage, root and shoot length and number of lateral roots

The effect of osmotic stress induced by PEG 6000 on germination percentage of 14 cowpea genotypes are presented in Table 3. As the PEG 6000 concentration increased, there was decrease in the germination percentage. The highest germination percentage was recorded at $T_{0}$ (control), as well as at T1 (lower PEG treatment) and at T2 (moderate PEG 6000 treatment), but at T3 (high concentration of PEG treatment) ITG7k-449-35 was unable de germinate and the germination percentage for most cowpea genotypes were below $50 \%$ germination. At high concentration, high germination percentage was recorded in RAPHAEL (88\%) followed by TAWA (71.11\%) and EGINWOGOGO (60\%). The germination percentage of each cowpea genotype in control and PEG induced water stress were statistically significant.

Most of cowpea varieties showed common trend reduction rate in root length with increasing concentration of PEG (Table 4) with the exception for RAPHAEL, IT07K-243-1-10, EGINWOGOGO, IT86D-888 and KVX-61-1, which exhibited the longest root at high concentration of PEG 6000 (16,50\%) when compared to the control, low and moderate treatments. The longest roots at $16.50 \%$ were recorded in KVX-61-1 $(5.27 \mathrm{~cm})$ followed by RAPHAEL $(5.08 \mathrm{~cm})$ and EGINWOGOGO $(5.05 \mathrm{~cm})$.

For TILIGRE, SEWE, KPODJI, KVX-61-1, IT07K-243-1-10 and TAWA, there was common trend in reduction rate of number of lateral roots with the increase in the concentration of PEG 6000 (Supplementary Figure 1). The results also revealed that with increase in PEG concentration, the number of lateral roots increased in RAPHAEL, IT86D-888, IT99K-573-2-1, IT84D-449 and ITG7K449-35. The highest number of lateral roots was recorded in RAPHAEL (11.67) at moderate concentration and that of high concentration was recorded with IT84D-449 (8.34) followed by EGINWOGOGO (7.56) and RAPHAEL (7.43).

The effect of water stress through PEG 6000 on shoot length are presented in Table 5. The response of cowpea genotypes differed significantly $(P<0.05)$ at different concentration of PEG 6000. All the cowpea genotypes showed reduction in shoot length as the concentration of PEG increased. For TILIGRE, ITG7K-449-35, KPODJI, KVX-61-1, IT84D-449 and IT99K-573-2-1, shoot lengths were completely inhibited at $16.50 \%$. The highest shoot lengths were recorded with IT07K-243-1-10 $(1.90 \mathrm{~cm})$ and IT86D-888 $(1.90 \mathrm{~cm})$ followed 
by RAPHAEL $(0.5 \mathrm{~cm})$. The significant decrease in values of the shoot compared to the roots indicated that in some genotype's drought caused a promotion of root growth.

\section{Effect of drought on morphological characters}

Drought stress decreased plant height, leaf length and leaf width in all genotypes at the vegetative stage investigated (Tables 6, 7, and 8). Drought induced a significant reduction in plant height of water stressed plants as compared to control (reduction varied from $9.58 \%$ in KPODJI to $34.53 \%$ in TILIGRE).

There were also significant differences among genotypes in respect to leaf length response to water stress (reduction varied from $11.76 \%$ in KOMCALLE to $38 \%$ in IT86D-888) (Table 7)

In all cowpea genotypes under a condition of drought stress leaf width decreased compared to fully watered plants (Table 8). Highly significant differences were observed with leaf width compared to other vegetative growth parameters (plant height and leaf length). The reduction varied from $7.78 \%$ in EGINWOGOGO to $47.05 \%$ in TILIGRE.

\section{Effect of drought on chlorophyll level}

Figure 2 below shows the effect of water stress on chlorophyll on each variety under different level of treatment. Treatment 2 that represents the moderate drought stress shows varieties RAPHAEL LOCALE and IT99K573-2-1 with low chlorophyll content as the most affected by water stress with TILIGRE and KOMCALLE recording high chlorophyll content and in treatment 3 , severe drought stress, TILIGRE and KVX-61-1 were recorded to have higher chlorophyll content as they were least affected by water stress while TAWA and ITG7K-449-35 had lower chlorophyll content as a result of a higher effect of water stress on them.

\section{Drought effect on days to flowering}

There was also a difference in the days to flowering of the varieties based on their treatment levels as shown in supplementary Table 1. Varieties like TAWA and EGINWOGOGO were the most affected under Moderate drought stress with both having a longer day to flowering (57\&60 days) respectively and IT84D-449 and IT86D-888 were least affected with shorter days to flowering, 47 and 48 days respectively. Under severe drought stress, variety IT07K-243-1-19 (62 days) and ITG7K-449-35, SEWE and TAWA recorded at 60days were the most affected by water stress while variety IT86D-888 (52 days) and KPODJI, KVX-611 recorded at 55 days were affected the least by water stress.

According to the dendrogram (Figure 3), genotypes were classified into four major groups: group 1 consists of 3 genotypes (RAPHAEL, EGINWOGOGO and TAWA) the most tolerant group 2 comprises IT99K-573-2-1, IT86D-888 and KVX-61-1 the moderately tolerant genotypes, group 3 were of 3 genotypes: SEWE, TILIGRE and IT84D-449 the susceptible genotypes and group 4 consists of 5 genotypes: KOMCALLE, KPODJI, ITG7K-449-35, IT84D-449 and ITO7K243-1-10 the most susceptible genotypes.

\section{Discussion}

Water stress has been a serious menace to crop production worldwide (Cairns et al., 2013; Upadhyaya et al., 2017; Ravelombola and Shi, 2018). Drought condition is one of the most significant abiotic factors that limit the germination of seed, plants growth and development and yield (Hartmann et al, 2005, Van den Berg and Zeng, 2006). While Hall (2012) observed that some cowpea plants grown in the Sahelian region showed some level of vegetative stage drought resistance on the same field and in conditions where pearl millet and peanuts were killed, the highest concentration of PEG in this experiment significantly affected the germination percentage of the 14 varieties of cowpea that were planted. The results of Allah et al (2018) presented evidence that root length is a useful parameter to determine how productive a plant can be, especially under drought conditions and variety KVX-61-1 had the longest root growth; this goes to say that this variety stands the best chance of being the most productive as it has an increased chance of accessing the zilch or at best, limited resources that typically characterize drought conditions. Lateral root growth has largely been assumed to imply efficiency in the search for water which is in short supply under drought conditions but an experiment by Zhan et al (2015) debunks those assumptions as the experiment showed that when plants roots branch out in the search for scarce resources in drought conditions, plants most of the time end up spending a lot of their energy and resources in vain and are better off channeling these resources towards primary root growth. In short, under drought conditions, the more lateral root growth a plant undertakes, the less likely such a plant can be characterized as an efficient plant; IT84D-449 was observed to have the highest lateral growth under the highest concentration of PEG 6000 in all 14 varieties considered in this research and can therefore be assumed to be an inefficient plant for selection in a drought-tolerant cowpea plant breeding programme while IT86D-888 exhibited the longest primary roots indispensable for searching water in the depth. Many studies have showed the importance of root architecture for enhancing drought tolerance in cowpea (Burridge et al.; 2017; Ajayi et al., 2018). Deep root systems are vital for the absorption of water from deeper soil layers in drought conditions (Matsui and Singh, 2003). It was observed that the more plants increased in primary roots the less the plants decreased in shoot length and lateral roots as shown in Figure 1 and Tables 4 and 5. In the same way, Wasaya et al. (2018) and Santos et al. (2020) demonstrated that plants may augment root length using various processes including increased biomass allocation or enhancing primary root formation while eliminating lateral root growth.

Shoot growth has also been found to be a key factor that determines drought resistance (Polania et al., 2017). In the laboratory experiment, all the 14 varieties of cowpea considered under this research were shown to have an inhibited shoot growth at the highest concentration of PEG 6000 . The variety which produced the highest root growth under the treatment had a shoot growth of less than $2 \mathrm{~cm}$. This implies a reduced ability to produce leaves which are necessary for food manufacture through photosynthesis. This trickles down to the plant's ability to pod when the time comes as the nodes will not even be able to produce flowers even if the roots are able to pick up some moisture and nutrients. Similarly, in the field experiment, the cowpea plants placed under drought conditions were significantly stunted in height and produced smaller leaves (leaf length and leaf breadth). The stunting observed in the plant population was so severe in some cases that it produced an almost $40 \%$ stunting in growth in relation to a normal, healthy plant grown under water-rich conditions. These observations corroborate the findings of Santos et al. (2020) 
Table 1. List of varieties used in the two experiments.

\begin{tabular}{|l|l|}
\hline Varieties & Varieties \\
\hline TILIGRE & IT84D-449 \\
\hline ITG7K-449-35 & ITO7K-243-1-10 \\
\hline KOMCALLE & IT99K-573-2-1 \\
\hline KPODJI-GUEGUE & TAWA \\
\hline SEWE & IT86D-888 \\
\hline KVX-61-1 & RAPHAEL \\
\hline IT84D-449 & EGINWOGOGO \\
\hline
\end{tabular}

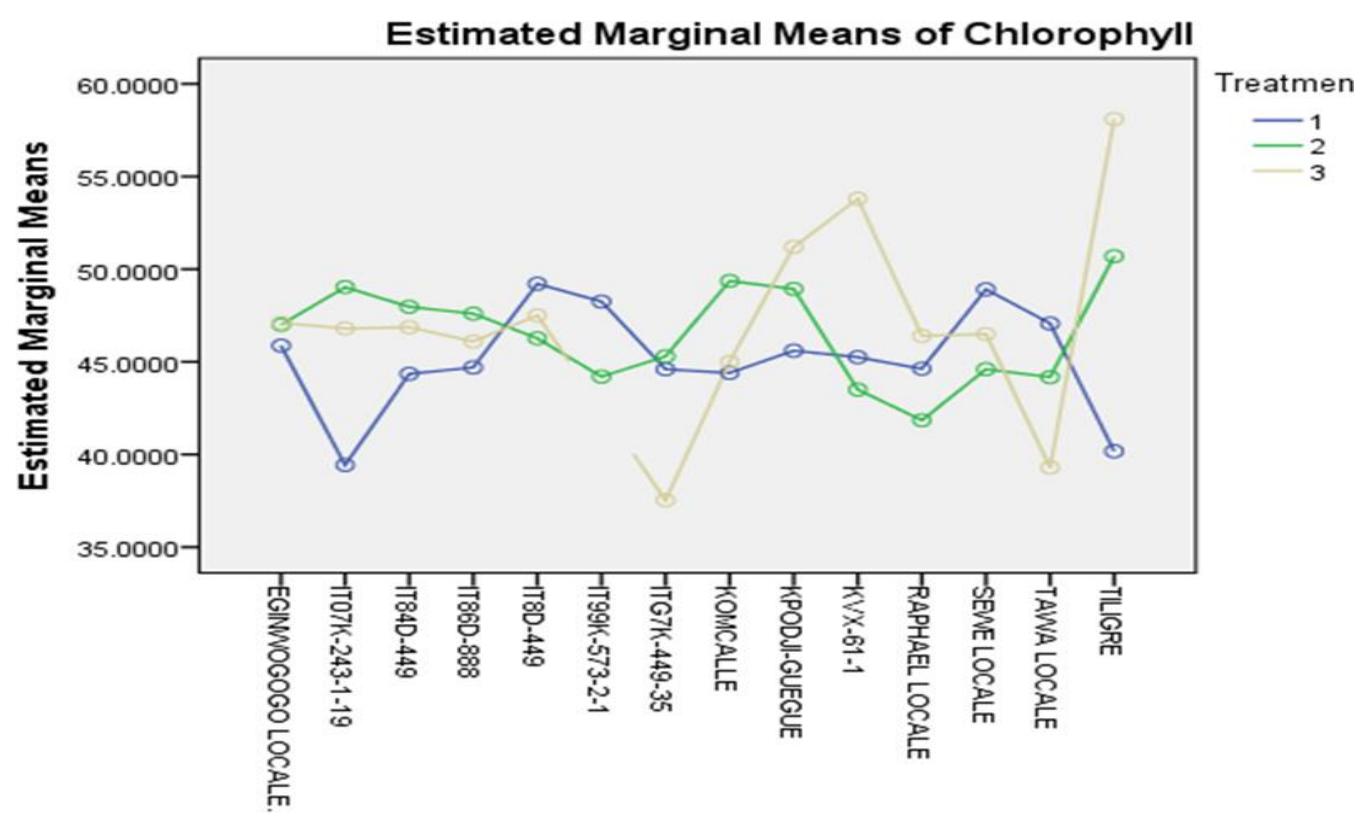

VARIETY

Non-estimable means are not plotted

Figure 2. Effect of water stress on chlorophyll content of different varieties used. $1=$ Control; $2=$ moderate drought; $3=$ severe drought.

Table 3. Effect of PEG 6000 on germination percentage.

\begin{tabular}{|l|l|l|l|l|}
\hline Variety & $0 \%$ & $6.5 \%$ & $13 \%$ & $16.5 \%$ \\
\hline TILIGRE & $100 \mathrm{a}$ & $95.56 \mathrm{a}$ & $37.78 \mathrm{~b}$ & $13.33 \mathrm{c}$ \\
\hline ITG7K-449-35 & $93.33 \mathrm{a}$ & $80 \mathrm{a}$ & $30.32 \mathrm{~b}$ & $0 \mathrm{c}$ \\
\hline KOMCALLE & $100 \mathrm{a}$ & $93.78 \mathrm{a}$ & $28.89 \mathrm{~b}$ & $2.22 \mathrm{c}$ \\
\hline KPODJI & $100 \mathrm{a}$ & $95.56 \mathrm{a}$ & $93.33 \mathrm{a}$ & $22.22 \mathrm{~b}$ \\
\hline SEWE LOCALE & $80 \mathrm{a}$ & $68.89 \mathrm{~b}$ & $46.67 \mathrm{c}$ & $15.56 \mathrm{~d}$ \\
\hline KVX-61-1 & $100 \mathrm{a}$ & $100 \mathrm{a}$ & $77.78 \mathrm{~b}$ & $46.67 \mathrm{c}$ \\
\hline IT84D-449 & $97.78 \mathrm{a}$ & $100 \mathrm{a}$ & $48.89 \mathrm{~b}$ & $11.11 \mathrm{c}$ \\
\hline IT84D-449 & $100 \mathrm{a}$ & $91.11 \mathrm{a}$ & $68.89 \mathrm{~b}$ & $15.56 \mathrm{c}$ \\
\hline IT07K-243-1-10 & $96.50 \mathrm{a}$ & $60.32 \mathrm{~b}$ & 20 & 22.22 \\
\hline IT99K-573-2-1 & 93.65 & 93.33 & 44.44 & 38.17 \\
\hline TAWA & 100 & 100 & 91.11 & 71.11 \\
\hline IT86D-888 & 100 & 100 & 71.11 & 31.11 \\
\hline RAPHAEL & 100 & 100 & 97.78 & 88.89 \\
\hline EGINWOGOGO & 100 & 97.78 & 95.78 & 59.86 \\
\hline
\end{tabular}

Means with the same alphabet within a row are not significantly different from one another at $P \leq 0.05$ using LSD. 


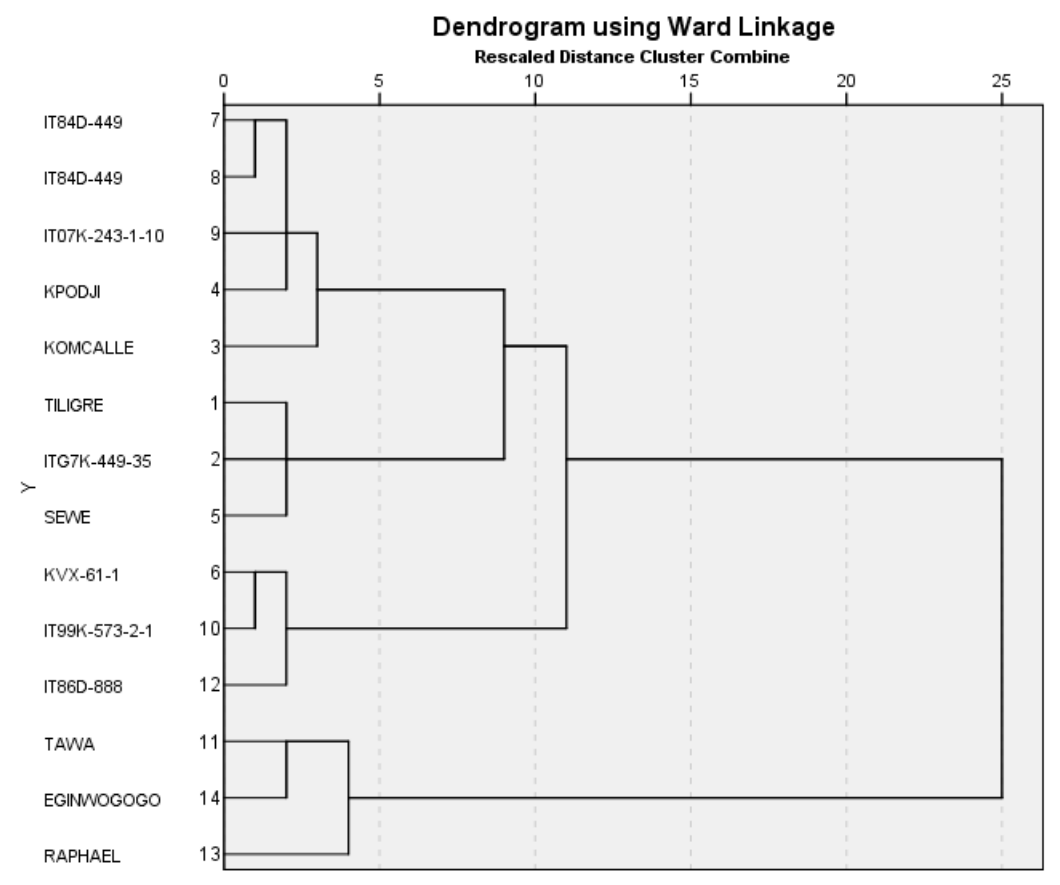

Figure 3. Dendrogram results obtained from germination and morphological data (shoot length, root length and germination percentage at $16.50 \%$ PEG 6000 and reduction of plant height, leaf length and width at severe drought) of 14 cowpea genotypes.

Table 4. Effect of PEG 6000 on root length.

\begin{tabular}{|l|l|l|l|l|}
\hline Variety & $0 \%$ & $6.5 \%$ & $13 \%$ & $16.5 \%$ \\
\hline TILIGRE & 4.17 & 3.38 & 2.56 & 2.05 \\
\hline ITG7K-449-35 & 3.40 & 2.61 & 2.17 & 0 \\
\hline KOMCALLE & 2.27 & 2.96 & 2.27 & 0.78 \\
\hline KPODJI & 3.35 & 5.27 & 2.97 & 3.86 \\
\hline SEWE LOCALE & 6.06 & 1.70 & 1.66 & 0.65 \\
\hline KVX-61-1 & 3.40 & 2.75 & 3.27 & 5.27 \\
\hline IT84D-449 & 5.84 & 5.65 & 5.56 & 1.05 \\
\hline IT84D-449 & 4.81 & 5.75 & 4.42 & 1.4 \\
\hline ITO7K-243-1-10 & 2.07 & 2.1 & 2.56 & 2.87 \\
\hline IT99K-573-2-1 & 3.21 & 2.82 & 1.76 & 1.3 \\
\hline TAWA & 5.34 & 4.90 & 3.65 & 3.00 \\
\hline IT86D-888 & 3.06 & 4.76 & 5.2 & 5.6 \\
\hline RAPHAEL & 4.55 & 4.39 & 5.83 & 5.08 \\
\hline EGINWOGOGO & 3.29 & 2.97 & 4.92 & 5.05 \\
\hline
\end{tabular}

Table 5. Effect of PEG 6000 on shoot length.

\begin{tabular}{|l|l|l|l|l|}
\hline Variety & $0 \%$ & $6.5 \%$ & $13 \%$ & $16.5 \%$ \\
\hline TILIGRE & $1.54 \mathrm{a}$ & $0.68 \mathrm{ab}$ & $0.4 \mathrm{~b}$ & $0 \mathrm{~b}$ \\
\hline ITG7K-449-35 & $2.85 \mathrm{a}$ & $1.27 \mathrm{~b}$ & $0.5 \mathrm{bc}$ & $0 \mathrm{c}$ \\
\hline KOMCALLE & $2.34 \mathrm{a}$ & $1.14 \mathrm{~b}$ & $0.6 \mathrm{~b}$ & $0.2 \mathrm{~b}$ \\
\hline KPODJI & $3.06 \mathrm{a}$ & $1.31 \mathrm{~b}$ & $0.18 \mathrm{c}$ & $0 \mathrm{c}$ \\
\hline SEWE LOCALE & $2.23 \mathrm{a}$ & $1.68 \mathrm{a}$ & $0.41 \mathrm{~b}$ & $0.1 \mathrm{~b}$ \\
\hline KVX-61-1 & $3.47 \mathrm{a}$ & $1.17 \mathrm{~b}$ & $0.74 \mathrm{bc}$ & $0 \mathrm{c}$ \\
\hline IT84D-449 & $1.33 \mathrm{a}$ & $0.69 \mathrm{a}$ & $0 \mathrm{~b}$ & $0 \mathrm{~b}$ \\
\hline IT84D-449 & $3.32 \mathrm{a}$ & $0.96 \mathrm{~b}$ & $0.6 \mathrm{~b}$ & $0.1 \mathrm{~b}$ \\
\hline ITO7K-243-1-10 & $2.46 \mathrm{a}$ & $2.81 \mathrm{a}$ & $2.18 \mathrm{a}$ & $1.9 \mathrm{a}$ \\
\hline IT99K-573-2-1 & $1.70 \mathrm{a}$ & $0.74 \mathrm{ab}$ & $0.2 \mathrm{~b}$ & $0 \mathrm{~b}$ \\
\hline TAWA & $3.39 \mathrm{a}$ & $1.74 \mathrm{~b}$ & $0.8 \mathrm{c}$ & $0.4 \mathrm{c}$ \\
\hline IT86D-888 & $4.43 \mathrm{~b}$ & $8.27 \mathrm{a}$ & $2.23 \mathrm{c}$ & $1.89 \mathrm{c}$ \\
\hline RAPHAEL & $2.87 \mathrm{a}$ & $2.38 \mathrm{a}$ & $0.6 \mathrm{~b}$ & $0.5 \mathrm{~b}$ \\
\hline EGINWOGOGO & $4.46 \mathrm{a}$ & $0.45 \mathrm{~b}$ & $0.47 \mathrm{~b}$ & $0.3 \mathrm{~b}$ \\
\hline
\end{tabular}

Means with the same alphabet within a row are not significantly different from one another at $P \leq 0.05$ using LSD 
Table 6. Effect of drought on plant height.

\begin{tabular}{|c|c|c|c|c|}
\hline Variety & Control & 18 days of drought & $\begin{array}{l}26 \text { days of } \\
\text { drought }\end{array}$ & $\begin{array}{l}\text { Plant height reduction (\%) } \\
\text { at severe drought }\end{array}$ \\
\hline TILIGRE & $32 a$ & $30.50 a$ & $20.95 b$ & 34.53 \\
\hline ITG7K-449-35 & $39.67 a$ & $32.27 a b$ & $29.35 b$ & 26.01 \\
\hline KOMCALLE & $31.00 a$ & $28.12 a$ & $26 b$ & 16.13 \\
\hline KPODJI & $36.55 a$ & $34.62 a$ & $33.05 a$ & 9.58 \\
\hline SEWE & $33.25 a$ & $25.90 \mathrm{~b}$ & $23.02 b$ & 30.77 \\
\hline KVX-61-1 & $36.37 a$ & $29.75 b$ & $29.10 b$ & 19.99 \\
\hline IT84D-449 & $34.25 a$ & $31.25 a$ & $28.42 a$ & 17.02 \\
\hline IT84D-449 & $36.45 a$ & $30.12 b$ & $29.17 b$ & 19.97 \\
\hline IT07K-243-1-10 & $39.42 a$ & $33.12 a b$ & $31.75 b$ & 19.46 \\
\hline IT99K-573-2-1 & $30.95 a$ & $30.20 a$ & $27.00 a$ & 12.76 \\
\hline TAWA & $32.87 a$ & $29.30 a$ & $27.75 a$ & 15.58 \\
\hline IT86D-888 & $39.35 a$ & $31.65 b$ & $30.62 b$ & 22.19 \\
\hline RAPHAEL & $36 a$ & $29.82 b$ & $27.47 b$ & 23.69 \\
\hline EGINWOGOGO & $33.42 a$ & $28.75 a b$ & $26.50 \mathrm{~b}$ & 20.71 \\
\hline
\end{tabular}

Means with the same alphabet within a row are not significantly different from one another at $\mathrm{P} \leq 0.05$ using LSD

Table 7. Effect of drought effect on leaf length.

\begin{tabular}{|c|c|c|c|c|}
\hline Variety & Control & 18 days of drought & 26 days of drought & $\begin{array}{l}\text { Leaf length reduction (\%) } \\
\text { at severe drought }\end{array}$ \\
\hline TILIGRE & 5.63aа & $5.2 \mathrm{a}$ & $4.25 b$ & 24.51 \\
\hline ITG7K-449-35 & $6.61 a$ & $6.02 \mathrm{ab}$ & $5.25 b$ & 20.57 \\
\hline KOMCALLE & $6.12 \mathrm{a}$ & $5.98 a$ & $5.40 a$ & 11.76 \\
\hline KPODJI & $7.17 a$ & $6.28 a b$ & $5.48 \mathrm{~b}$ & 23.57 \\
\hline SEWE & $6.17 a$ & $5.87 a$ & $5.10 \mathrm{~b}$ & 17.34 \\
\hline KVX-61-1 & $5.53 a$ & $4.38 \mathrm{~b}$ & $4.08 \mathrm{~b}$ & 26.22 \\
\hline IT84D-449 & $7.65 a$ & $5.96 \mathrm{~b}$ & $5.81 b$ & 24.05 \\
\hline IT84D-449 & $6.67 a$ & $5.48 \mathrm{~b}$ & $5.33 b$ & 20.09 \\
\hline IT07K-243-1-10 & $5.41 a$ & $5.55 a$ & $5.43 a$ & 15.29 \\
\hline IT99K-573-2-1 & $6.21 a$ & $4.63 b$ & $4.36 \mathrm{~b}$ & 29.79 \\
\hline TAWA & $6.38 a$ & $5.72 a$ & $5.62 a$ & 11.91 \\
\hline IT86D-888 & $8.47 a$ & $5.88 \mathrm{~b}$ & $5.25 b$ & 38.02 \\
\hline RAPHAEL & $7.18 a$ & $6.33 a$ & $6.31 a$ & 12.12 \\
\hline EGINWOGOGO & $6.38 a$ & $6.14 a$ & $5.60 a$ & 12.23 \\
\hline
\end{tabular}

Means with the same alphabet within a row are not significantly different from one another at $P \leq 0.05$ using LSD

Table 8. Effect of drought on leaf width.

\begin{tabular}{|c|c|c|c|c|}
\hline Variety & Control & 18 days of drought & $\begin{array}{l}26 \text { days of } \\
\text { drought }\end{array}$ & $\begin{array}{l}\text { Leaf width reduction } \\
(\%) \text { at severe drought }\end{array}$ \\
\hline TILIGRE & $6.27 a$ & $5.43 a$ & $3.32 b$ & 47.05 \\
\hline ITG7K-449-35 & $8.37 a$ & $4.88 \mathrm{~b}$ & $4.82 b$ & 42.41 \\
\hline KOMCALLE & $6.37 a$ & $5.65 a$ & $5.46 a$ & 14.29 \\
\hline KPODJI & $7.77 a$ & $6.25 b$ & $5.91 b$ & 23.94 \\
\hline SEWE & $7.16 a$ & $5.65 b$ & $4.88 b$ & 31.84 \\
\hline KVX-61-1 & $5.72 a$ & $4.84 a$ & $4.78 a$ & 16.43 \\
\hline IT84D-449 & $7.35 a$ & $6.07 \mathrm{~b}$ & $5.73 b$ & 22.04 \\
\hline IT84D-449 & $7.63 a$ & $6.78 \mathrm{ab}$ & $6.18 b$ & 19.00 \\
\hline IT07K-243-1-10 & $6.30 a$ & $5.53 a$ & $5.36 a$ & 14.92 \\
\hline IT99K-573-2-1 & $6.32 a$ & $5.60 a b$ & $5.17 \mathrm{~b}$ & 18.20 \\
\hline TAWA & $6.68 a$ & $5.15 b$ & $5.20 \mathrm{~b}$ & 22.16 \\
\hline IT86D-888 & $8.16 a$ & $6.08 b$ & $6.21 b$ & 23.90 \\
\hline RAPHAEL & $8.31 a$ & $4.87 b$ & $4.95 b$ & 11.55 \\
\hline EGINWOGOGO & $6.30 a$ & $5.97 a$ & $5.81 a$ & 7.78 \\
\hline
\end{tabular}

Means with the same alphabet within a row are not significantly different from one another at $P \leq 0.05$ using LSD. 
who reported that plants seem to devote itself to root formation especially the primary roots and decline shoot biomass.

The results of this experiment confirmed that despite the comparative tolerance to drought, cowpea exhibits significant genetic variation in response to water stress. In the field experiment, the plants placed under drought had a significant reduction in height and the leaves were also short (leaf length, leaf width and leaf area). Our findings are similar with those of Santos et al. (2020)

There is a statistically significant difference in all the morphological trait observed in the plant as a result of drought. The plants under control treatment had longer leaf length in comparison to the plants under moderate and severe drought conditions. Varieties like IT99K-573-2-1 and EGINWOGOGO, during the second year of experiment, show "DEAD" leaves under severe drought coupled with harmattan which shows that they cannot survive well in severe conditions. The plants under moderate and severe conditions had lower values in comparison to the plants under control drought condition. This shows that such susceptible plants loss their greenness thus preventing chlorosis. Same results were obtained by Santos et al. (2020) and Ravelombola et al. (2020). The days to flowering of the plants was also influenced by the drought conditions the plant was placed under. All the varieties treated under severe drought condition had a longer days to flowering than those under moderate and control conditions. In the field experiment and as shown in the data analyzed, some of the morphological traits observed were different for the plants based on their drought conditions and about 2 varieties (IT99K-573-2-1 and EGINWOGOGO) showed that it cannot reach optimum growth and development under severe drought conditions, those varieties should not be planted in areas that possess such condition. The inability of the roots of the plants to get enough water also showed in the growth of the plant and its leaves. This is in part because root length does not necessarily relate to more water extraction, and to the fact that having water available at critical crop stages is probably more crucial than having large water uptake overall (Vadez 2014). It was observed that within varieties, individual plants expressed varying levels of survival and recovery in response to drought stress. However, varieties such as IT8D-449 and TILIGRE that wilted fast at the beginning of the experiment had relatively lower recovery rate, the wilting was not associated to deep water extraction from the root as the varieties were planted in small buckets which means the variety does not easily retain water in the shoot.

\section{Materials and Methods}

\section{Plant materials and experimental location}

Fourteen Cowpea varieties were used in the present study (Table 1). They were obtained from the International Institute of Tropical Agriculture (IITA). The laboratory experiment was carried out at the Department of Environmental Management and Crop Production while the open field experiment was conducted at Bowen University Teaching and Research Farm Iwo, Osun State, Nigeria. Iwo is a City in Osun State, Nigeria. It has a latitude of $7^{\circ} 38^{\prime} 6.97^{\prime \prime}$ $\mathrm{N}$ and a longitude of $4^{\circ} 10^{\prime} 53.62^{\prime \prime} \mathrm{E}$.

The experiments were carried out over two years. The first year experiment was conducted from $10^{\text {th }}$ December 2018 to $28^{\text {th }}$ February 2019 and the second year from $28^{\text {th }}$
December 2019 to $25^{\text {th }}$ March 2020. The laboratory experiment was not carried out in the second year and lasted 14 days.

\section{Seed disinfection and germination screening using PEG 6000}

Seeds of cowpea varieties were surface-sterilized with $75 \%$ ethanol for $10 \mathrm{~min}$ followed by a 3-time washing with sterile distilled water. Then, 20 cowpea seeds were germinated on two layers of sterilized Whatman filter papers in $9 \mathrm{~cm}$ Petri dishes. Four treatments $0 \%, 6.5 \%, 13 \%$ and $16.5 \%$ PEG were prepared by adding $0 \mathrm{~g}, 65 \mathrm{~g}, 130 \mathrm{~g}$ and $165 \mathrm{~g}$ of PEG 6000 to 1liter, $935 \mathrm{ml}, 870 \mathrm{ml}$, and $835 \mathrm{ml}$ of distilled water, respectively. All the petri dishes were kept in the laboratory at a temperature of $25^{\circ} \mathrm{C} \pm 3$. 2. $5 \mathrm{ml}$ of distilled water and prepared PEG 6000 solutions were added to each petri dishes and frequently added to the petri dishes when the filter papers dried. The experimental design used was a completely randomized block design with three replications.

\section{Laboratory parameters Measurement}

The first reading of seed germination was performed 24 hours after sowing, and then the counting of the germinated seeds was continued every day until the 9th day of drought episode. Shoot length and root length of 3 seedlings from each petri dish and each block were measured on the 9th day. Other measurements taken were germination percentage and seed vigor index. Germination index (G.I.) was computed by using the following formula: G.I.=n/d, where $n$ is the number of seedlings emerging on day $d=$ day after sowing. Data was also taken on number of lateral roots.

\section{Open field pot experiment and experimental design}

Drought treatments were first initiated during the vegetative stage of plant development. 20-day-old plants were either irrigated daily or exposed to drought (no water) for 10 (moderate) or 15 (severe) days. A second episode of drought was initiated during the reproductive stage of plant development. Again, plants were either watered daily or exposed to drought for 9 (moderate) or 12 (severe) days. The same plants were used for each treatment during both episodes of drought.

Treatments [14 varieties $\times 3$ levels of drought (none, moderate, and severe)] were arranged in a split plot design with four replicate plants (pots) per treatment. The main plot consists of water stress while the subplot was cowpea varieties. Each block included four rows. The pots were spaced $20 \mathrm{~cm}$ apart within the rows and $75 \mathrm{~cm}$ apart between the rows with one plant per pot.

Measurement was taken on plant height, number of leaves, leaf length, chlorophyll content and days to flowering.

\section{Data analysis}

The average raw data of the two seasons was obtained before statistical analysis. Analysis of data recorded were subjected to statistical analysis using R statistic software to identify significant difference among cowpea varieties. ANOVA was performed for the assessment of the variation at 0.05 level of probability using LSD and Multiple Comparison-PostHOC test. In addition, hierarchical cluster between traits measured was determined.

\section{Conclusion}


In conclusion, this experiment has helped classify the 14 varieties of cowpea under evaluation into categories of drought tolerant and drought susceptible plants based on certain morphological characteristics that were measured. This data will be useful in determining which cowpea plants will be useful in designing a drought-tolerant breeding programme and in deciding which ones not to waste time including in the mix. For instance, RAPHAEL and TAWA varieties have been shown to be the most drought tolerant varieties of the 14 varieties under evaluation. In essence, these three varieties can be determined to give the most promising results if a breeding programme was to be set up. This will inevitably help save up resources that will ordinarily include the less tolerant varieties in a breeding programme. Moreover, harmattan accelerates dryness of soil and increases the drought stress in cowpea.

\section{Acknowledgments}

We are thankful to IITA from providing us with the cowpea seeds used in the experiments.

\section{References}

Almaghrabi OA (2012) Impact of drought stress on germination and seedling growth parameters of some wheat cultivars. Life Science Journal. 9, 590-598.

Ajayi AT, Gbadamosi AE, Olumekun VO (2018) Screening for drought tolerance in cowpea (Vigna unguiculata L. Walp) at seedling stage under screen house condition. Intl J Biotechnol. 11(1):1-9

Boyer JS (1982) Plant productivity and environment. Science. 218:443-448.

Burridge JD, Schneider HM, Huynh BL, Roberts PA, Bucksch A, Lynch JP (2017) Genome-wide association mapping and agronomic impact of cowpea root architecture. Theor Appl Genet. 130(2):419-431.

Cairns JE, Crossa J, Zaidi PH, Grudloyma P, Sanchez C., Araus JL, Thaitad S, Makumbi D, Magorokosho C, Banziger M, Menkir A (2013) Identification of drought, heat, and combined drought and heat tolerant donors in maize. Crop Sci. 53(4):1335-1346.

Carvalho M, Lino-Neto T, Rosa E, Carnide V (2017) Cowpea: A legume crop for a challenging environment. J Sci Food Agr. 97:4273-4284

Chinma CE, Alemede IC, Emelife IG (2008) Physicochemical and functional properties of some Nigerian cowpea varieties. Pak J Nutr. 7(1): 186-190.

Deikman J, Petracek M, Heard JE (2012) Drought tolerance through biotechnology: improving translation from the laboratory to farmers' fields. Curr Opin Biotechnol. 23: 243-250

Esan VI, Ayanbamiji TA, Adeyemo JO, Oluwafemi S (2018) Effect of drought on seed germination and early seedling of tomato genotypes using polyethylene glycol 6000. Int J Sci. 7(2): 36-43.

Ghebremariam KM, Liang Yan MA, Zhengcai Zhang MA, Qiaoli Wang MA (2013) Effect of drought stress on physiological growth parameters of tomato inbred lines at germination stage. Europ Sci J. 9(33): 25-33.

Hartmann M, College P, Lumsden (2005) Responses of different varieties of Loliumperenne to salinity. Annual Conference of the Society for Experimental Biology, Lancashire.
Khodarahmpour Z (2011) Effect of drought stress induced by polyethylene glycol (PEG) on germination indices in corn (Zea mays L.) hybrids. Afr J Biotech. 10: 18222-18227.

Kulkarni M, Deshpande U (2007. Gradient in vitro testing of tomato (Solanum lycopersicon) genotype by inducing by water deficit: a new approach to screen germplasm for drought tolerance. Asian J Plant Sci. 6(6):934:940.

Langyintuo AS, Lowenberg-DeBoer J, Faye M, Lambert D, Ibro G, Moussa B, Kergnae A, Kushwaha S, Musa S, Ntoukamg G (2003) Cowpea supply and demand in West and Central Africa. Field Crops Research. 82(2-3):215-231.

Lisar SYS, Motafakkerazad R, Hossain MM, Rahman IMM (20120 Water Stress in Plants: Causes, Effects and Responses, In Water Stress; Prof. Ismail Md. Mofizur Rahman Ed., InTech: New York, USA. DOI: 10.5772/39363. Available online:

http://www.intechopen.com/books/water-stress/waterstress-in-plants-causes-effects-andresponses.

Lo S, Muñoz-Amatriaín M, Hokin SA, Cisse N, Roberts PA, Farmer AD, Xu S, Close TJ (2019) A genome-wide association and meta-analysis reveal regions associated with seed size in cowpea [Vigna unguiculata (L.) Walp]. Theor Appl Genet. (2019) 132:3079-3087. https://doi.org/10.1007/s00122-019-03407-z.

Matsui T, Singh BB (2003) Root Characteristics in Cowpea Related to Drought Tolerance at the Seedling Stage. Exp. Agric. 39:29-38.

Olaoye G (2005) Developing drought tolerant crop varieties for the Savanna Agro-ecologies of Nigeria. Genetics and food security in Nigeria. $165-174$.

Owonubi JJ, Abdumumin S (1985) Forecasting drought in Nigeria. In David et al. (Eds) Drought in Africa 2. London. Int. Aft.icun Inst.54-63.

Rauf M, Munir M, Hassan M, Ahmad M, Afzal M (2006) Performance of wheat genotypes under osmotic stress at germination and early seedling growth stage. Afr J Biotechnol. 6: 971-975.

Ravelombola W, Shi A (2018) Investigation on various aboveground traits to identify drought tolerance in cowpea seedlings. Hortsci. 53(12):1757-1765. 2018. https://doi.org/10.21273/HORTSCI13278-18.

Ravelombola W, Shi A, Chen S, Xiong H, Yang Y, Cui Q, Olaoye D, Mou B (2020) Evaluation of cowpea for drought tolerance at seedling stage. Euphytica. 216:123 https://doi.org/10.1007/s10681-020-02660-4.

Robin S, Pathan MS, Courtois B, Lafitte R, Carandang S, Lanceras S, Amante M, Nguyen HT, Li Z (2003) Mapping osmotic adjustment in an advanced back-cross inbred population of rice. Theor Appl Genet. 107, 1288-1296.

Santos R, Carvalho M, Rosa E, Carnide V, Castro I (2020) Root and Agro-Morphological Traits Performance in Cowpea under Drought Stress. Agronomy. 10(1604): doi:10.3390/agronomy10101604.

Timko MP, Ehlers JD, Roberts PA (2007) Cowpea," in Pulses, Sugar and Tuber Crops, Genome Mapping and Molecular Breeding in Plants, C. Kole, Ed., vol. 3, pp. 49-67, Springer, Berlin, Germany.

Timko MP, Singh BB (2008) Cowpea, a multifunctional legume in Genomics of Tropical Crop Plants, P.H. Moore and R.Ming,Eds.,pp.227 258, Springer, NewYork, NY, USA, 2008. 
Tuberosa R (2012) Phenotyping for drought tolerance of crops in the genomics era. Front Physiol. 3: 347-359.

Upadhyaya HD, Dwivedi SL, Vetriventhan M, Krishnamurthy L, Singh. SK (2017) Postflowering drought tolerance using managed stress trials, adjustment to flowering, and mini core collection in sorghum. Crop Sci. 57(1):310-321.

Van den Berg L, Zeng YJ (2006) Response of South African indigenous grass species to drought stress induced by polyethylene glycol (PEG) 6000. Afr J Bot. 72: 284-286.
Wasaya A, Zhang X, Fang Q, Yan Z (2018) Root Phenotyping for Drought Tolerance: A Review. Agronomy. 8: 241.

Weng Y, Shi A, Ravelombola WS, Yang W, Qin J, Motes D, Moseley DO, Chen P (2017) A rapidmethod formeasuring seed protein content in cowpea (Vigna unguiculata (L.) Walp)). Amer J Plant Sci. 8(10):2387-2396. 